\title{
КОМПЛЕКС ВПРАВ ДЛЯ ФОРМУВАННЯ КОМУНІКАЦЙНИХ НАВИЧОК У ПРОЦЕСІ ПРОФЕСІЙНО-ОРІЄНТОВАНОГО НАВЧАННЯ ІНОЗЕМНОЇ МОВИ МАЙБУТНІХ ФАХІВЦІВ ЕКОНОМІЧНОГО ПРОФІЛЮ
}

\begin{abstract}
Вишневська К.Г. Комплекс вправ для формування комунікаційних навичок у прочесі професійно-орієнтованого навчання іноземної мови майбутніх фахівиів економічного профілю.

У статті розглянуто зміст, типологію $і$ засади, на яких трунтується розробка комплексу вправ до експериментальної програми професійно-орієнтованого навчання іноземної мови майбутніх фахівиів економічного профілю.

Ключові слова: комунікачійні навички, експериментальна програма, навчання іноземної мови.

Вишневская К. Г. Комплекс упражнений для формирования коммуникативных навыков в профессионально-ориентированном обучении иностранному языку будущих специалистов экономического профиля.

В статье рассмотрены содержание, типология и принципы, на которых основана разработка комплекса упражнений, входящих в экспериментальную программу профессиональноориентированного обучения иностранному языку будущих специалистов экономического профиля.

Ключевые слова: коммуникационные навыки, экспериментальная программа, обучение иностранному языку.

Vyshnevska K. A set of exercises for the formation of communicative skills in the professionaloriented foreign language teaching future professionals in economics.

The article considers the content, typology, and the principles on which set of exercises experimental program professionally-oriented foreign language teaching future professionals of the economy is based.
\end{abstract}

Key words: communication skills, an experimental program, learning a foreign language.

Інтернаціоналізація і транснаціоналізація бізнесу висувають вимогу ефективного спілкування учасників міжнародних ділових стосунків. Оскільки українська мова не має статусу мови міжнародного спілкування, то саме оволодіння іноземною мовою міжнародного спілкування і готовність до іншомовного спілкування у побутовій та професійній областях набуває особливого значення, стає критерієм професійності і конкурентоздатності сучасного фахівця. Це повною мірою стосується фахівців економічного профілю, чия професійна діяльність безпосередньо пов'язана 3 обслуговуванням ділових процесів - їх плануванням, прогнозуванням, аналізом, організацією. Для підвищення рівня мовної підготовки майбутніх фахівців економічного профілю необхідне удосконалення змісту, форм і методів іншомовної підготовки шляхом впровадження адекватних вимогам часу технологій навчання.

Проблеми професійно орієнтованого підходу до навчання іноземної мови в умовах вищого навчального закладу задля формування іншомовної комунікативної компетенції досліджували Т. Алексєєва, Л. Ананьєва, Т. Астафурова, М. Бовтенко, Н. Гаврилюк, Л. Гапоненко, Л. Гейхман, О. Горбуненко, Л. Девіна, 
Н. Дудко， В. Касьянова， І. Клейман， Е. Комарова， М. Кузьміна, І. Куліш, Е. Мірошніченко, Н. Пустовалова, С. Романенко, С. Селіверстов, Г. Скуратівська, О. Тарнопольский та інші. Формування у студентів англомовної професійно спрямованої компетенції в говорінні вивчали І. Коломієць, Л. Котлярова, А. Литнєва, Л. Манякіна, Е. Мірошниченко, Ю. Пассов, В. Скалкін, Н. Скляренко, О. Тарнопольський та інші. Методику формування іншомовної комунікативної компетенції досліджували І. Берман, В. Бухбіндер, В. Коростильов, С. Шатілов, В. Гнаткевич, Ю. Пассов, Г. Китайгородська, О. Тарнопольський, Е. Мірошниченко, І. Баценко, В. Борщовецька та інші.

Мета навчання іноземної мови майбутніми фахівцями економічного профілю полягає у формуванні вмінь, навичок мовлення і готовності до його застосування як інструмента комунікації та засобу розв'язання професійних завдань. Сучасний економіст має бути здатним до самостійного встановлення контактів з іноземними партнерами, ведення перемов, вести ділове листування, правильно складати ділові папери, опрацьовувати фахову інформацію з іншомовних джерел. Однією з проблем мовної освіти щодо формуванні іншомовної професійно спрямованої комунікативної компетентності $\epsilon$ адекватне вимогам часу і середовища методичне забезпечення процесу іншомовного навчання.

У сучасних методичних підходах до іншомовної підготовки не надається переваги якомусь одному в чистому вигляді методу або технології, а тісно переплетені прийоми різних методик навчання: комунікативної, активної, інтерактивної, контекстної. Таке поєднання дозволяє використати весь спектр методичного і дидактичного інструментарію, що передбачає практичне оволодіння всіма видами мовленнєвої діяльності як засобу спілкування, що спрямоване на обмін інформацією [2], вмотивованої комунікативною потребою (комунікативний метод) в процесі активної взаємодії студентів і викладача (метод активного навчання) [3, с. 30], а також студентів між собою (інтерактивне навчання) 3 використанням ігрових $\mathrm{i}$ ситуативних завдань (притаманне всім зазначеним методам), моделювання (імітацію) у навчальному процесі предметного i соціального змісту діяльності майбутнього фахівця [1, с. 4], ситуації спілкування.

Проте велика кількість теоретичних досліджень не зумовила розроблення універсальних програм навчання і методичного забезпечення до них, що враховують специфіку фахової підготовки, вхідний рівень умінь та навичок студентів.

Мета статті полягає у висвітленні практичного досвіду автора із створенням комплексу вправ для навчання професійно орієнтованої іноземної мови майбутніх фахівців економічного профілю.

У межах експериментальної програми 3 професійно орієнтованого навчання іноземної мови майбутніх економістів було розроблено спецкурси «Англійська мова $з$ поглибленим вивченням» та «Ділова англійська мова» для студентів III-IV курсів спеціальності «Банки». До спецкурсів включено комплекс вправ ігрового та імітаційно-рольового характеру, різних за 
структурою, установкою та способом виконання. Вправами охоплено всі види пізнавальної діяльності - від репродуктивної до творчої. Розроблена система вправ націлена на формування:

- умінь побудови змістовного висловлювання за моделлю;

- умінь вільно оперувати мовним матеріалом;

- професійно спрямованої комунікативної компетенції в предметній області економічних дисциплін.

Комплекс вправ грунтується на засадах:

- загальнодидактичних - свідомості, активності і самостійності; систематичності та послідовності; наочності; науковості; доступності i посильності;

- загальнометодичних - комунікативної спрямованості навчання іноземної мови, рівневого підходу до знань і вмінь студентів, домінуючої ролі вправ;

- методичних - розумово-мовленнєвої активності, індивідуалізації при провідній ролі особистісного аспекту, ситуаційності, функціональності, тематичності, новизни [4, с. 5-6].

Комплекс вправ для формування іншомовної професійно спрямованої комунікативної компетентності майбутніх фахівців економічного профілю задовольняє наступним вимогам: послідовність і врахування зростання мовної та операційної складності процесу навчання; дотримання трьох етапів становлення мовленнєвих умінь (осмислення матеріалу і формування мовленнєвих навичок; удосконалення сформованих мовленнєвих навичок та етапів розвитку мовленнєвих умінь); урахування закономірності формування мовленнєвих умінь у говорінні; раціональна організація і включення серій вправ; урахування повторюваності і циклічності навчального матеріалу; наявність контролю.

За складністю вправи розподілено на чотири рівні, розрізняються за спрямованістю на сприйняття і відтворення інформації і враховують ступінь оволодіння мовленням.

Вправи розробленої експериментальної програми характеризується багатоаспектністю вирішуваних завдань. Адаптуючи до завдань експериментальної програми типологію вправ Н. Скляренко [4], до комплексу включено вправи, що різняться за:

- функціями: навчальні - сприяють розвитку загальнонавчальних умінь і навичок, таких як пам'ять, увага, сприйняття інформації різної модальності, умінь і навичок мовлення рідною і іноземною мовами; виховні моделюють поведінку в ігрових моделях, життєвих ситуаціях; навчальновиховні - сприяють оволодінню іноземною мовою, враховуючи аспект виховання; розважальні - створюють сприятливу невимушену атмосферу занять; комунікативні - об'єднують студентів у єдиний колектив, допомагають встановленню емоційних контактів, сприяють формуванню навичок й умінь спілкування; розвивальні - сприяють гармонійному розвитку особистих якостей для активізації резервних можливостей; 
- психічним впливом: релаксаційні - знімають емоційне напруження, що викликане навантаженням на нервову систему під час занять; стимулюючі - стимулюють процеси мислення, запам'ятовування, відтворення дійсності (імітаційні здібності); спрямовуючі - спонукають студента до діяльності на занятті;

- дидактичною метою мовлення: спрямовані на оволодіння монологічним мовленням, тобто зв'язним безперервним висловлюванням однієї особи, спрямованим одному або кільком співрозмовникам; спрямовані на оволодіння діалогічним мовленням, тобто сприяють формуванню процесу розмови двох партнерів, який не планують заздалегідь;

- етапом ведення заняття: початкового етапу заняття для введення студента до іншомовної діяльності; для введення нового матеріалу; для закріплення нового матеріалу; на вільне використання вже знайомого матеріалу; для повторення навчального матеріалу;

- використанням мовного матеріалу: лексичні - спрямовані на відпрацювання лексичних одиниць, враховуючи їх особливості; фонетичні для оволодіння специфікою вимови звуків англійської мови та інтонацією англійської мови; граматичні - для оволодіння граматикою англійської мови; 3 відтворення середовища: навчальні - основні ігрові вправи під час навчального процесу - передають атмосферу на занятті, спонукають студента активно працювати на занятті; ділові - проектують майбутню професійну діяльність (менеджера, фінансиста); рольові - спрямовані на добровільне входження до ролі і використання реплік, слів, які найкраще характеризують цю роль; вправи-уявлення, що переносять учасника в уявний світ, де він матиме змогу за допомогою іноземної мови відобразити свої почуття; творчі, мистецькі - для оволодіння специфічною економічною лексикою; вправи-фантазії, схожі на вправи-уявлення, допомагають студенту за допомогою іноземної мови завершити ситуацію, початок якої був запропонований викладачем;

- віком учасників ігрових вправ: для першокурсників; для студентів II-III курсів; для студентів випускних курсів бакалаврів та магістрів безпосередньо спрямовані на сприйняття серйозного складного матеріалу.

- пізнавальні: вправи-ознайомлення, коли відбувається ознайомлення студента 3 матеріалом, під час якої від студента не вимагається його використання; вправи-дотики - зі спробою використати матеріал, пропустити його крізь себе; глибинні вправи, що вимагають володіння й можливості використання основного й допоміжного навчального матеріалу; за способом організації: парні, групові та індивідуальні. Ми використовували всі перераховані за способом організації типи ігрових вправ, проте перевага надавалась парним та груповим видам роботи, в яких імовірність виникнення спонтанного діалогічного або монологічного мовлення є найбільш можливою;

Комплекс вправ розроблено і впроваджено нами у процесі реалізації експериментальної програми щодо професійно орієнтованого навчання майбутніх фахівців економічного профілю. 
Наведемо приклади вправ із тієї частини комплексу, що застосовувались на першому, когнітивно-збагачувальному етапі експериментальної програми. На меті цього етапу було збагачення мовлення студентів іноземною лексикою професійно-орієнтованої спрямованості; навчання їх проектуванню варіативних професійно спрямованих мовленнєвих ситуацій іноземною мовою, будувати відповідні діалоги, полілоги, монологи.

Вправи I рівня мають на меті навчити студентів «реплікування», тобто швидко адекватно реагувати на подану викладачем/диктором репліку, а також продукувати ініціативну репліку. У такий спосіб формуються вміння ведення керованого діалогу та монологу. I рівень включає некомунікативні або умовно-комунікативні, рецептивно-репродуктивні або репродуктивні невмотивовані вправи 3 повним керуванням та поданими опорами - на імітацію, підстановку трансформацію, відповіді на запитання, повідомлення або запит певної інформації, спонукання до певних дій тощо. Типові режими роботи викладача та студентів у процесі виконання вправ цього рівня: викладач-група / група-викладач; викладач-студент1, викладач-студент2, студент1-викладач, студент2-викладач .

Вправа I рівня. Мета - формування мовних навичок, а саме лексичних за темою «Покупки» і граматичних за темою «Модальні дієслова у їх другому значенні та розвиток говоріння в діалогічній формі».

Вправа спрямована на самостійне вживання мовленнєвого зразка, репліки студентів - ініціативні.

Мета вправ II рівня - навчити студентів самостійно вживати різні види діалогічної єдності. Основний режим роботи - «студент 1 - студент $2 »$, тобто робота студентів у парах. Вправи цього рівня є умовно-комунікативними, рецептивно-продуктивними, вмотивованими на обмін репліками, 3 частковим керуванням та поданими опорами. При організації роботи студентів в парах необхідно надавати можливість вживати як реактивну, так i ініціативну репліку. Роботу в парах слід інтенсифікувати через одночасне включення до роботи всіх студентів на місцях і в русі, використовуючи прийом «карусель».

Вправа II рівня.

Мета: Розвиток мовленнєвих умінь і навичок говоріння в монологічній/діалогічній формах за темою «Реклама. Маркетинг».

1 етап.

Викладач: Answer the questions of «Money Survey» and compare the answers. If you have the same relation to money you may go shopping together. If not, give your groupmate advice how to save.

\begin{tabular}{|c|c|}
\hline Варіант 1 & Bаріант 2 \\
\hline $\begin{array}{l}\text { 1-й студент. You and me usually } \\
\text { know, how much we have in our purse } \\
\text { and never waste money for } \\
\text { unnecessary things, let's shop together. }\end{array}$ & $\begin{array}{l}\text { 1-й студент. You should always pay } \\
\text { cash when you go shopping, if you use } \\
\text { credit cards spending can get out of } \\
\text { control. }\end{array}$ \\
\hline $\begin{array}{l}\text { 2-й студент. With pleasure. But first } \\
\text { we are to prepare shopping lists. }\end{array}$ & $\begin{array}{l}\text { 2-й студент. Right you are. Using a } \\
\text { credit card gives me the illusion, that } \\
\text { no money is being spent. }\end{array}$ \\
\hline
\end{tabular}


2 етап.

Викладач: Using pictures of stores and supermarkets define the ways which managers and logistics use in order to get the buyers to spend as much money as possible.

1-й студент. Look at the prices given in the shop-windows. The final figure is 9. Don't you think it's a trick?

2-й студент. I'm afraid it is. Shops often charge $99 \mathrm{p}$ for things to create the illusion that they cost much less than a pound.

3-й студент. And those customers in the bakery are sure to take so many loaves and buns because of spreading the smell of fancy pastry in the supermarket.

3 етап. Викладач пропонує скласти діалоги за картками, заповнюючи пропуски словами за власним бажанням.

1-й студент. I'd like to have... to match this...

2-й студент. Are you sure this ... snits you?

3-й студент. This... fits your...

1-й студент. Won't... stretch with...?

2-й студент. How about... . It looks...

1-й студент. I don't feel... in this... could you...

3-й студент. Try these... a real bargain.

1-й студент. But won't it shrink after...

3-й студент. We've sold dozens of and haven't had a single...

2-й студент. Food choice they will wear for...

3-й студент. There is your..., sir. Pay at the... thank you.

Мета вправ III рівня - навчити студентів об'єднувати засвоєну діалогічну єдність у мікродіалоги згідно з запропонованими їм навчальними ситуаціями. До цієї групи входять вмотивовані комунікативні рецептивнопродуктивні вправи нижчого рівня з частковим керуванням. Їм властиві наявність мовленнєвого завдання, ситуативної спрямованості фраз, заданість мовленнєвої діяльності, наявність штучно створених вербальних опор.

Вправа III рівня.

Діалог-гра «Організація ділової подорожі».

Мета - розвиток мовленнєвих умінь (говоріння в монологічній / діалогічній формах за темою «Ділові перемови», аналітичного читання.

Вправи IV рівня мають на меті навчити студентів розв'язувати поставлену задачу, створюючи власні діалоги різних функціональних типів (аналітичні, критичні, дискусійні) без зосередження на формі висловлювання. Опорою може бути рекламна листівка, картка із завданням або оголошенням. Це вмотивовані комунікативні рецептивно-продуктивні вправи вищого рівня 3 мінімальним керуванням, без вербальних опор. Продукт мовлення студентів - діалог певного функціонального типу, що включає принаймні два (рідше - три) мікродіалоги.

Вправа IV рівня.

Мета - розвиток мовленнєвих вмінь (говоріння в діалогічній формі за темою «реклама», аналітичне мислення. 
Викладач: The representative of British advertising company in Ukraine wants to set an advertising agency subsidiary. He needs selling representatives to distribute facilities, managers and brand managers. It's a well-known fact that people of various occupations can work for advertising. During the interview the applicants should answer the questions: what is advertising? What are three main goals of advertising? What are the main obligations of advertising manager? Does this work give opportunities for good promotion?

Вправа виконувалась в режимі одночасної роботи студентів у групах по три з використанням прийому «натовп» або прийому «навчаючи - вчуся» Єдина опора, що надавалась, інформаційний листівка - об'ява про вакансії у рекламному агентстві.

Діалоги за наведеними вправами відбувались протягом 5-10 хвилин, далі -5 хвилин на схвалення та корегування помилок. Робився акцент або на швидкому мовленні так, щоб комунікація була якомога більш спонтанною, або на правильності мовлення, вимагаючи від студентів дуже ретельно формулювати свою думку. Діалоги демонструвались по черзі парами перед рештою студентів або всіма парами водночас. Тоді викладач пересувався між студентів, прислухаючись. В останньому випадку після закінчення вправ викладач привертав увагу аудиторії до двох-трьох проблем, що виникли в роботі більш, ніж однієї пари, і вже потім окрема пара демонструвала свій діалог з урахуванням зауважень викладача. Діалог-гра проходив значно цікавіше, якщо на різних етапах партнери змінювались ролями. Студенти 3 високим рівнем знань допомагали менш обізнаним перекладати та обговорювати завдання, подане в картках, що сприяло створенню партнерської атмосфери.

Приклад імітаційно-рольової гри, що входить до комплексу вправ на подальшому етапі реалізації експериментальної програми професійноорієнтованого навчання, а також порівняльну оцінку рівня сформованості іншомовних комунікативних умінь студентів до i після впровадження експериментальної програми наведено в іншій статті автора [4].

Отже, нами розроблено і впроваджено експериментальну програму професійно-орієнтованого навчання іноземної мови майбутніх фахівців економічного профілю, що містить вправи для формування і вдосконалення навичок i вмінь із побудування змістовного висловлювання за моделлю, вільного оперування мовним матеріалом. Визначено вимоги до вправ i їх компонентів, уточнено їх типологію. Ефективність застосування розробленої системи вправ підтверджена результатами завершального тестування, що засвідчив позитивну динаміку зміни рівня оволодіння професійноспрямованим іноземним мовленням майбутніх фахівців економічного профілю. Подальші дослідження передбачають пошук шляхів підвищення іншомовної професійно-мовленнєвої культури майбутніх фахівців економічного профілю. 


\section{Література}

1. Вербицкий А. А. Педагогические технологии контекстногообучения: [научнометодич. пособие] / А. А. Вербицкий. - М. : РИЦ МГГУ им. М.А. Шолохова, 2010.- 55 с.

2. Мильруд Р. П. Современные концептуальные принципы коммуникативного обучения иностранным языкам/ Р. Мильруд, И. Максимова // Иностранные языки в школе. - 2000. - № 4.- С. 9-13.

3. Програма 3 англійської мови для професійного спілкування: [Текст] / Г.Є. Бакаєва, О.А. Борисенко, І.І. Зуєнок, В.О. Іваніщева, Л.Й. Клименко, Т.І. Козимирська, С.І. Кострицька, Т.І. Скрипник, Н.Ю. Тодорова, А.О. Ходцева. - К.: Ленвіт, 2005. - 199 с.

4. Скляренко Н. К. Типологія вправ в інтенсивному навчанні іноземних мов / Н. К. Скляренко // Гуманістичні аспекти лінгвістичних досліджень і методики викладання іноземних мов. - К.: КДПІІМ, 1992. - С. 9-13.

Стаття надійшла до редакції 28.05.2012 p.

УДК 378.091.12.011.3

Т. М. Яблонська, кандидат пед. наук, доцент, Південноукраӥнський національний університет ім. К.Д. Ушинського

\section{ПРО РОЛЬОВУ ПЕРСПЕКТИВУ У СТРАТЕГІЇ ПІДИЩЕННЯ ЯКОСТІ ПЕДАГОГІЧНОЇ ПІДГОТОВКИ МАЙБУТНІХ УЧИТЕЛІВ-ФІЛОЛОГІВ}

Яблонська Т. М. Про рольову перспективу у стратегії підвищення якості педагогічної підготовки майбутніх учителів-філологів.

У статті подано теоретичне обтрунтування рольової перспективи як головної ідеї в стратегії підвищення якості педагогічної підготовки майбутніх учителів-філологів, розкриваються ії сутність та професіональний підхід.

Ключові слова: рольова перспектива, стратегія підвищення якості педагогічної підготовки, рольова ситуачія.

Яблонская Т. М. О ролевой перспективе в стратегии повышения качества педагогической подготовки будущих учителей-филологов.

В статье даётся теоретическое обоснование ролевой перспективы как ведущей идеи в стратегии повышения качества педагогической подготовки будущих учителей-филологов, раскрываются её сущность и пути реализаџии в учебном процессе.

Ключевые слова: ролевая перспектива, стратегия повышения качества педагогической подготовки, ролевая ситуачия.

Yablonckaya T. About role perspective in the strategy of future-teachers-philologists' pedagogical training quality raising.

The theoretical ground of the role perspective as the main idea of the strategy of future teachersphilologists' pedagogical training quality raising, its essence and the ways of realization in the teaching process are discovered.

Key words: role perspective, the strategy of pedagogical training quality raising, role situation.

Постановка проблеми. Аналіз педагогічної літератури і практики вищої педагогічної школи дає підстави говорити про те, що результативність педагогічної підготовки майбутніх учителів-філологів багато в чому визначається зміною характеру стосунків пї учасників, переходом від педагогічного впливу до діалогічної взаємодії викладача і студентів, що вибудовується, незважаючи на розбіжність поглядів, позицій, настанов, на 